\title{
Tingkat Keterampilan Teknik Dasar Push and Stop pada UKM Hoki Stkip Pasundan
}

\author{
Levels of Push and Stop Basic Technique Skills \\ in Unit Student Activity Hockey Stkip Pasundan
}

\author{
Yudi Hidayat \\ STKIP Pasundan, Cimahi, Jawa Barat, Indonesia \\ hidayatyudi.zyss69@gmail.com
}

\begin{abstract}
Abstrak
Penelitian ini bertujuan untuk mengetahui tingkat keterampilan teknik dasar push and stop pada unit kegiatan mahasiswa (UKM) hoki STKIP Pasundan Cimahi. Metode penelitian yang digunakan adalah deskriptif kuantitatif dengan pendekatan survei. Populasi dan sampel dalam penelitian ini adalah seluruh mahasiswa yang mengikuti unit kegiatan mahasiswa (UKM) cabang olahraga hoki di STKIP Pasundan Cimahi yang berjumlah kurang lebih 15 orang. Instrumen yang digunakan dalam penelitian ini adalah Tes keterampilan passing and stop. Teknik analisis yang dilakukan adalah menuangkan frekuensi ke dalam bentuk persentase. Hasil penelitian ini menujukkan bahwa sebanyak 9 orang atau 60\% pada kategori baik sekali , katogiri baik 5orang atau 33.3\% , kategori cukup 1 orang atau $6.6 \%$ dan 0 rang atau $0 \%$ untuk kategori kurang dan kurang sekali.
\end{abstract}

Kata Kunci: Push and stop, Hoki

\begin{abstract}
This study aims to determine the level of basic push and stop technical skills at the STKIP Pasundan Cimahi hockey student activity unit (UKM). The research method used is descriptive quantitative with a survey approach. The population and sample in this study were all students who participated in the student activity unit (UKM) of hockey in the STKIP Pasundan Cimahi, which numbered approximately 15 people. The instrument used in this study is the passing and stop skill test. The analysis technique carried out is to pour the frequency into a percentage. The results of this study show that as many as 9 people or $60 \%$ in the excellent category, either speak 5 people or $33.3 \%$, enough categories 1 person or $6.6 \%$ and 0 rang or $0 \%$ for the category of less and less once.
\end{abstract}

Keywords: Push and stop, Hockey 


\section{PENDAHULUAN}

Di Indonesia olahraga hoki yang berkembang adalah hoki field dan hoki ruangan (indoor). Hoki field dimainkan dilapangan terbuka seperti di rumput dan di karpet diaminkan oleh 11 orang pemain dalam satu tim. Sedangkan hoki ruangan (indoor) jumlah pemain dalam satu tim 5 orang. Carsiwan (2014:1) mengatakan Olahraga hoki adalah salah satu olahraga permainan yang dimainkan oleh dua regu yang setiap pemainnya menggunakan suatu tongkat yang ujungnya melengkung (stick) dan bola. N Saputri (2017) Hoki adalah permainan yang dimainkan antara dua regu yang masing-masing regu menggunakan tongkat bengkok atau stik (stick) untuk menggerakan bola. Jane Powell dalam Marhadi (2012) mengatakan permainan hoki adalah sebuah permainan tim yang menyenangkan, cepat dan membutuhkan keterampilan.

Push (mendorong) merupakan suatu teknik passing yang umum digunakan dalam permainan hoki. Push pass biasa digunakan pada jarak 4,5 - 13,8 m. Dalam push pass ada hal penting yang harus diperhatikan yaitu akurasi, kecepatan gerakan, dan merubah arah. Akurasi push pass dipengaruhi oleh posisi kaki serta keseimbangan tubuh. Mendorong (push) adalah salah satu bentuk teknik dasar dengan cara mendorong bola yang dalam permainan hoki digunakan untuk mengoper bola kepada teman, dengan jarak yang dekat ataupun jauh dan menjadi tembakan kegawang. Feri Kurniawan (2012:87) mengatakan Tehnik mendorong (push) dapat digunakan untuk memberikan umpan ataupun untuk menembak ke gawang, sangatlah tepat digunakan untuk operan jarak jauh, sedangkan stoping adalah menghentikan bola dengan menggunakan stick yang di pegang dengan dua tangan, jikalau terpaksa dapat dilakukan dengan satu tangan.

Tidak dipungkiri perkembangan hoki yang begitu pesat berdampak pada penyelenggaraan kejuaraan olahraga di sekolah. Dulunya ekstrakurikuler olahraga hanya sebatas olahraga tertentu seperti sepakbola, bolavoli, bolabasket, badminton, dan lain sebagainya, tetapi saat ini hoki merupakan salah satu olahraga favorit di sekolah-sekolah menengah pertama atau menengah atas maupun universitas. Karena banyak sekali manfaat yang didapat dalam olahraga hoki. Sebagaimana yang dikatakan oleh Carsiwan dan Sandrawaty (2016) bahwa Kegiatan ekstrakurikuler olahraga hoki yang dilakukan memiliki pengaruh terhadap kebugaran jasmani dan percaya diri siswa.

UKM hoki merupakan salah satu UKM di STKIP Pasundan yang cukup diminati. Meskipun ukm hoki cukup disenangi, tetapi kemajuan ukm hoki di SMA STKIP Pasundan tergolong lambat dan bisa dikatakan mengalami kemunduran, Dibandingkan dengan tahun - tahun sebelumnya yang berhasil menorehkan prestasi di berbagai turnamen. Hal ini disebabkan oleh berbagai faktor diantaranya adalah durasi latihan yang kurang, karena lapangan yang masih menggunakan lapangan serbaguna, sehingga 
jadwal latihan harus berbagi dengan UKM lain. Hal inilah yang sekiranya dapat menghambat perkembangan teknik, fisik maupun mental para mahasiswa, karena faktor tersebut yang dapat mempengaruhi prestasi atau performa seorang atlet. Terutama pada aspek teknik, yang merupakan faktor dasar dalam sebuah permainan olahraga yang harus dimiliki dengan baik oleh para pemain.

Berdasarkan hal tersebut, peneliti tertarik untuk melakukan penelitian tentang sejauh mana penguasaan teknik dasar push dan stop para mahasiswa yang tergabung dalam UKM Hoki di STKIP Pasundan. Karena peneliti rasakan teknik push dan stop ini yang banyak sering dilakukan dalam permainan hoki. Sebagaimana penelitian yang dilakukan oleh Rozi dalam Budiarto dan Bawono (2014) yang menunjukan bahwa teknik push digunakan mencapai 49,09\%, hit 33,42\%, tepping 17,49\%. Sehingga tujuan dari penelitian ini nantinya adalah dapat menggambarkan seberapa besar penguasaan teknik dasar push dan stop dalam olahraga hoki.

\section{METODE}

Metode yang digunakan dalam pelitian ini adalah deskriptif kuantitatif dengan pendekatan survei. Populasi dalam penelitian ini adalah seluruh anggota UKM Hoki STKIP Pasundan sebanyak 15 orang. Sampel yang digunakan adalah seluruh populasi, artinya 15 orang populasi dijadikan sampel. Teknik ini disebut juga total sampling atau sampling jenuh. Sugiyono (2018:85) mengatakan Sampling jenuh adalah teknik penentuan sampel bila semua anggota populasi digunakan sebagai sampel. Hal ini sering dilakukan bila jumlah populasi relatif kecil, kurang dari 30 orang. Instrument yang digunakan adalah tes push dan stopping permainan hoki yang telah diuji tingkat validitas dan reliabilitasnya. Sedangkan untuk teknik analisis data yang digunakan adalah dengan menggunakan persentase.

\section{HASIL DAN PEMBAHASAN}

\section{Hasil}

Berdasarkan hasil observasi dan pengamatan yang telah dilakukan di lapangan, maka dapat diperoleh hasil sebagai berikut:

Tabel 1. Deskripsi Data

\begin{tabular}{ccc}
\hline Variabel & Rata-Rata & Simpangan Baku \\
\hline Push and Stop & 16.67 & 1.34 \\
\hline
\end{tabular}

Berdasarkan tabel 1 tersebut dapat diketahui bahwa nilai rata-rata dari hasil tes push and stop pada UKM Hoki STKIP Pasundan adalah sebesar 16,67 sedangkan simpangan bakunya adalah sebesar 
1,34. Untuk lebih jelasnya sebaran data hasil tes push and stop pada permainan hoki dapat dilihat pada tabel dan diagram berikut:

\section{Tabel 2. Sebaran Hasil Tes Push and Stop pada UKM Hoki STKIP Pasundan}

\begin{tabular}{ccccc}
\hline Presentasi & Rentang skor & Nilai produk & Frekuensi & Persentasi \\
\hline $\mathbf{8 0 - 1 0 0 \%}$ & $16-20$ & Baik sekali & 9 & $60 \%$ \\
\hline $\mathbf{6 6 - 7 9 \%}$ & $14-15$ & Baik & 5 & $33.3 \%$ \\
\hline $\mathbf{5 6 - 6 5 \%}$ & $12-13$ & Cukup & 1 & $6.6 \%$ \\
\hline $\mathbf{4 1 - 5 5 \%}$ & $9-11$ & Kurang & 0 & 0 \\
\hline $\mathbf{0 - 4 0 \%}$ & $0-8$ & Kurang sekali & 0 & 0 \\
\hline & JUMLAH & & $\mathbf{1 5}$ & $\mathbf{1 0 0}$
\end{tabular}

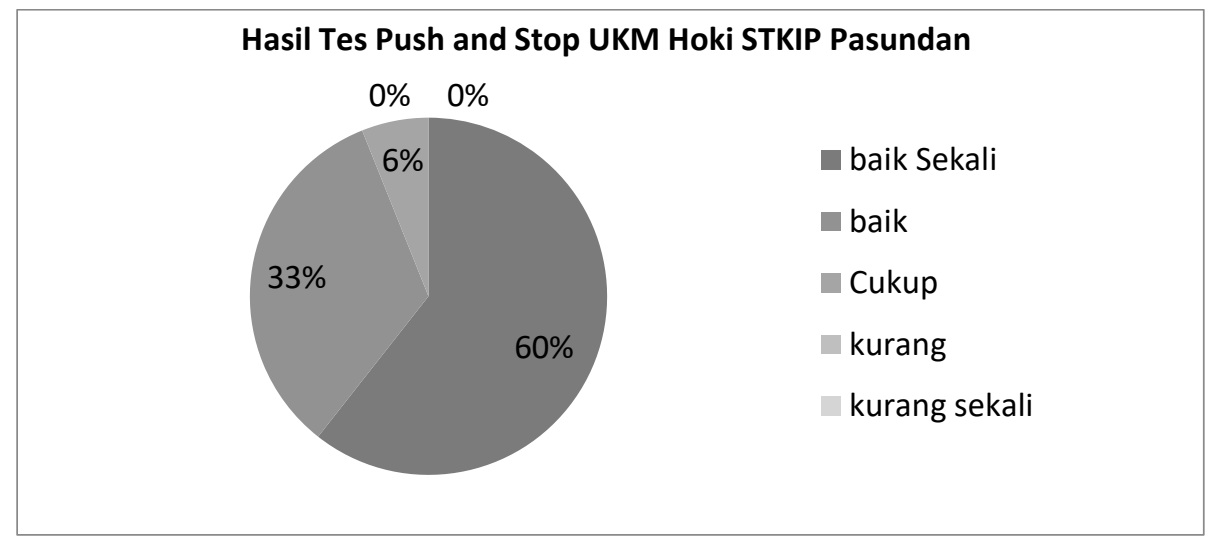

Gambar 1. Diagram Hasil Tes Push and Stop

Dari tabel dan diagram di atas dapat diketahui bahwa Tingkat Keterampilan Teknik Dasar push and stop pada unit kegiatan mahasiswa (UKM) hoki STKIP Pasundan Cimahi adalah baik dengan pertimbangan frekuensi terbanyak berapa pada kategori baik sekali dengan 9 orang atau 60\%, katogiri baik 5orang atau 33.3\%, kategori cukup 1 orang atau $6.6 \%$ dan 0 rang atau $0 \%$ untuk kategori kurang dan kurang sekali.

\section{Pembahasan}

Berdasarkan hasil penelitian yang telah dilakukan dapat diketahui bahwa hasil tes push and stop mahasiswa yang mengikuti UKM Hoki di STKIP Pasundan rata-rata memiliki keterampilan yang baik sekali. Hal ini dikarenakan keseriusan dan ketekunan mahasiswa dalam berlatih membuat performa meningkat, terutama dalam teknik push and stop, walaupun belum berdampak pada prestasi UKM Hoki STKIP Pasundan. Hal ini dikarenakan tidak hanya teknik push dan stop saja yang perlu dikuasai, tetapi teknik lain seperti dribbling, shooting,hit dan flick, yang tentunya dapat mempengaruhi terhadap kualitas permainan tim. 
Salah satu faktor penting dalam pencapaian prestasi adalah dengan latihan yang sesuai. Inilah yang sekiranya menyebabkan kualitas permainan UKM Hoki STKIP Pasundan belum mencapai prestasi yang diharapkan, karena frekuensi latihan yang hanya sekali dalam seminggu, sehingga dirasakan kurang. Padahal Giriwijoyo (2013:53) mengatakan minimal frekuensi latihan dalam satu minggu adalah 3 kali. Selain faktor latihan ada beberapa faktor yang mempengaruhi kualitas permainan, menurut Putra (2017) Setidaknya ada dua faktor, yaitu faktor internal dan eksternal. Internal berkaitan dengan minat dan motivasi dari diri sendiri, sedangkan faktor eksternal diantaranya ada pelatih, sarana prasarana, dan lingkungan.

Berkaitan dengan hal tersebut, jelas bahwa selain penguasaan teknik dasar yang baik dibutuhkan juga latihan yang intensif, tim pelatih yang berkualitas, sarana prasarana yang memadai, serta lingkungan yang mendukung terhadap pelaksanaan olahraga yang berkaitan dengan cabang olahraga hoki, karena percuma jika teknik dasar dikuasai dengan baik, tapi komponen yang lainnya seperti fisik, taktik, mental dan juga fasilitas kurang mendukung. Hal ini tidak akan berpengaruh terhadap kualitas permainan.

\section{KESIMPULAN}

Berdasarkan hasil penelitian dan pembahasan yang telah dipaparkan maka dapat dimbil kesimpulan bahwa tingkat keterampilan teknik dasar push and stop pada unit kegiatan mahasiswa (UKM) hoki STKIP Pasundan Cimahi adalah baik dengan pertimbangan frekuensi terbanyak berapa pada kategori baik sekali dengan 9 orang atau 60\%, katogiri baik 5orang atau 33.3\%, kategori cukup 1 orang atau $6.6 \%$ dan 0 rang atau $0 \%$ untuk kategori kurang dan kurang sekali.

Disarankan kepada semua pihak terkait, baik para pelatih, mahasiswa juga lembaga lebih memperhatikan jadwal latihan dan fasilitas yang digunakan, jangan sampai ingin menuntut prestasi yang tinggi, tetapi tidak didukung dengan aspek-aspek lain yang dapat berpengaruh lebih besar terhadap peningkatan prestasi.

\section{DAFTAR PUSTAKA}

Carsiwan dan Sandrawaty, M. (2016). Pengaruh Pembelajaran Permainan Hoki Terhadap Kebugaran Jasmani Dan Kepercayaan Diri Siswa Di Sma Negeri 26 Garut. Jurnal Terapan Ilmu Keolahragaan, Vol. 01(02), p. 56-63.

Carsiwan. (2014). Pembelajaran Permainan Hoki. Bandung: Bintang WarliArtika.

Giiwijoyo, S. (2013). Ilmu Faal Olahraga (Fisiologi Olahraga). Bandung: PT. Rosdakarya. 
Kurniawan, F. (2012). Buku Pintar Pengetahuan Olahraga. Jakarta: Perpustakaan Nasional RI.

Mahardi. (2012). Developing Hockey Game For Learning Media Of Physical Education Sport And Health To Junior High School Students. Journal of Physical Education and Sport, Vol. 1(1), p. 48-59.

Putra. (2017). Survei Keterampilan Dasar Bermain Sepakbola Siswa Putera Usia 10-12 Tahun Di SD Muhammadiyah Siraman. Skripsi: Prodi. PJKR FIK UNY.

Rozi dalam Budiarto, T F dan Bawono. (2014). Perbandingan Kecepatan Laju Bola Pada Jenis Pukulan Push, Hit dan Flick Dalam Permainan Hockey. Jurnal Kesehatan Olahraga, Vol. 02(02), p. 120-128.

Saputri, N. (2017). Pengembangan Alat Dan Model Permainan Hoki Untuk Pembelajaran Pendidikan Jasmani Anak Sekolah Dasar Kelas Atas. Online: http://journal.student.uny.ac.id/ojs/index.php/pgsd-penjaskes/article/download/7742/7365

Sugiyono. (2018). Metode Penelitian Kuantitatif, Kualitatif dan R\&D. Bandung: Alfabeta. 